\title{
PHENOTYPIC DIVERSITY AND BIOCHEMICAL CHARACTERISTICS OF SELECTED RHIZOBIA NODULATING THE COMMON BEAN (Phaseolus vulgaris L.)
}

\author{
Saoussen Kouki ${ }^{1}$, Boulbaba L'taief ${ }^{1,2}$, Rahamh N. Al-Qthanin ${ }^{2}$, \\ Mustapha Rouissi ${ }^{3}$ and Bouaziz Sifi ${ }^{1}$
}

\begin{abstract}
Increasing interest in using rhizobia as biofertilizers in smallholder agricultural farming systems has prompted scientists to investigate rhizobia diversity, resulting in the identification of many strains. Fifty-five Rhizobium strains nodulating in the common bean (Phaseolus vulgaris L.) were isolated from soil samples from different areas of Tunisia and phenotypically characterized to determine their symbiotic nitrogen fixation capabilities. Their tolerance to $\mathrm{pH}$, salinity, temperature and alkalinity, as well as their cultural and biochemical characteristics indicated wide physiological diversity. These phenotypic characteristics significantly affected rhizobia growth, and strains of interest were identified and used in inoculation trials. They were efficient and able to tolerate $\mathrm{pH}$ from 4 to $9, \mathrm{NaCl}$ concentrations of 25 to $100 \mathrm{mM}$, temperature variation from 10 to $40{ }^{\circ} \mathrm{C}$, and lime $\left(\mathrm{CaCO}_{3}\right)$ from 0.05 to $0.20 \mathrm{mM}$. Selected Rhizobium strains were identified as candidates for biofertilizer production for a variety of Tunisian soil types.

Additional keywords: Biodiversity, Rhizobium, salinity, temperature
\end{abstract}

\section{RESUMEN}

Diversidad fenotípica y características bioquímicas de cepas de Rhizobium nodulando el frijol (Phaseolus vulgaris L.) El creciente interés en el uso de rizobios como biofertilizantes en sistemas agrícolas de pequeña escala ha llevado a investigar su diversidad, lo que ha resultado en la identificación de muchas cepas. En este studio se aislaron 55 cepas de Rhizobium que nodulaban en frijol común (Phaseolus vulgaris L.) en muestras de suelo de diferentes áreas de Túnez y se caracterizaron fenotípicamente para determinar su capacidad de fijación simbiótica de nitrógeno. Su tolerancia a la salinidad, $\mathrm{pH}$, temperatura y alcalinidad, asì como las características culturales y bioquímicas indicaron una amplia diversidad fisiológica. Estas características fenotípicas afectaron significativamente el crecimiento de los rizobios, los cuales se identificaron y las cepas de interés se utilizaron en ensayos de inoculación. Estas cepas fueron eficientes y capaces de tolerar un $\mathrm{pH}$ de 4 a 9 , concentraciones de $\mathrm{NaCl}$ de $25 \mathrm{mM}$ a $100 \mathrm{mM}$, variaciones de temperatura entre 10 y $40{ }^{\circ} \mathrm{C}$, y encalado $\left(\mathrm{CaCO}_{3}\right)$ de 0,05 a $0,20 \mathrm{mM}$. Se identificaron cepas de Rhizobium como candidatas para la producción de biofertilizantes para una variedad de tipos de suelos tunecinos.

Palabras clave adicionales: Biodiversidad, Rhizobium, salinidad, temperatura

\section{INTRODUCTION}

The common bean (Phaseolus vulgaris L.) is a widely cultivated food crop, representing $50 \%$ of the leguminous grain directly consumed by humans. It provides a good source of plant proteins, potentially reducing animal consumption. It is also an important energy

Received: January 15, 2021

source. In addition to the dietary benefits, the bean can also benefit agricultural production; in this sense, Meng (2015) noted that the benefits of yield increase of bean are associated with biofertilizers.

One of the significant features of the common bean plant is its capability of establishing a symbiotic relationship with specific bacteria and

${ }^{1}$ Laboratory of Agronomic Sciences and Technology, National Institute of Agronomic Research of Tunisia (INRAT).

University of Carthage. Tunis, Tunisia. e-mail: saoussenkouki71@yahoo.fr; sifi.bouaziz@iresa.agrinet.tn

${ }^{2}$ Biology Department, College of Sciences, King Khalid University, P.O. Box 960, Abha, Saudi Arabia.

e-mail: lboulaba@yahoo.com (corresponding author); rngerse@kku.edu.sa

${ }^{3}$ Applied Biotechnology Laboratory, National Institute of Agronomic Research of Tunisia (INRAT). University of Carthage. Tunis, Tunisia. e-mail: mustapha_rssi@yahoo.fr 
developing biological $\mathrm{N}_{2}$ fixation in root nodules that provides required $\mathrm{N}$ to the plant (Hungria et al., 2003; Mwenda et al., 2018; El Attar et al., 2019). The $\mathrm{N}_{2}$ fixation process is associated with the host plant's physiological state in the Rhizobium-legume symbiosis. Therefore, a rhizobial strain may not express its full capacity for $\mathrm{N}_{2}$ fixation, specifically if certain soil or environmental factors limit the vigour of the host legume. These factors may include extreme temperature or unfavourable soil $\mathrm{pH}$ or salinity, among others (Kaymakanova et al., 2008; Cao et al., 2014; Hungria et al., 2015). Stressors might exert multiple effects; for example, salinity might lead to water stress (affecting the photosynthetic rate) or directly impact nodule initiation and metabolism. The most challenging environments for rhizobia are marginal land that receives minimal precipitation, experiences high temperatures and has acidic soil with low nutrient concentrations and poor water holding capacity (Bargaz et al., 2012; Kumar et al., 2016; Chekani et al., 2018).

In some of these regions, inoculation of crops with non-native strains of common bean rhizobia has been utilized to improve crop production, but those areas experienced extremely low yields. The limited yield was not attributed to the nitrogenfixing potential of the common bean-Rhizobium symbiosis but the symbiont's non-adaptability to the osmotic stress prevailing in those regions. Arid soils may contain strains adapted to the severe environmental stresses of $\mathrm{pH}$ variation, high soil temperature and drought (Musandu and Ogendo, 2001; Yanni et al., 2016). These strains should be considered for use as ban inoculants in regions facing severe water shortages. Their successful inoculation depends on their $\mathrm{N}_{2}$ fixation capabilities and adaptability to adverse soil conditions, such as increased drought and salinity. The current research aims to examine the phenotypic diversity and nodulation ability of the adapted and efficient rhizobia nodulating Phaseolus vulgaris L. in Tunisia to select the best strain for the production of biofertilizer inoculants in the region.

\section{MATERIALS AND METHODS}

Bacterial strains and culture conditions. Fiftyfive rhizobia isolates were extracted from root nodules of common beans (Phaseolus vulgaris L.) during the flowering stage. Following the criteria defined by Vincent (1970), one isolate was extracted from each nodule. Yeast extractmannitol (YEM) medium was used to cultivate, purify and isolate these rhizobia. The strains were stored in tubes at $4{ }^{\circ} \mathrm{C}$ on YEM agar media. Table 1 provides a list of all isolates.

Symbiotic traits. A common bean variety, 'Coco Blanc' registered in the official Tunisian catalogue, was used as plant material. 'Coco Blanc' seeds were sterilized for 1 minutes with calcium hypochlorite $(3 \%)$, then washed gently four times with distilled water. They were allowed to germinate in Petri dishes with sterile moistened blotting paper for three days. The Laboratory of Agricultural Sciences and Techniques, National Institute of Agronomic Research in Tunisia (INRAT, Tunisia) provided local and introduced rhizobia and common bean seeds (Table 1). Rhizobial inoculants prepared as liquid cultures in YEM medium $\left(10^{9}\right.$ cells $\left.\cdot \mathrm{mL}^{-1}\right)$ were introduced by soaking seedlings for 30 minutes in the inoculants before transplanting into plastic growth pots $(0.5 \mathrm{~kg}$ of sterile perlite). The nodulation parameters and their effects on nodule number and biomass were measured for 55 infective strains. Symbiotic testing of the rhizobia strains was replicated four times. Irrigation was performed twice weekly, adding $40 \mathrm{ml}$ of a nutrient solution without nitrogen to each pot (Vincent, 1970). Results are shown in Table 1. A non-inoculated common bean was used as a control to assess both nodule number and biomass and shoot and root biomass.

Physiologic and biochemical tests. Other than biochemical substrate assimilation, all tests were conducted in triplicate on $24 \mathrm{~cm}^{2}$ YEM agar plates divided into 20 equal squares. Each square was spot-inoculated with $10 \mu \mathrm{l}$ of the strain culture previously used as the liquid medium in the exponential phase $\left( \pm 10^{9} \quad\right.$ cells $\left.\cdot \mathrm{mL}^{-1}\right)$. The inoculated plates were incubated at $28{ }^{\circ} \mathrm{C}$ for six days at which time the colony growth was visually monitored. The classification of the strains (from very sensitive to tolerant) was based on measuring the bacterial colonies diameters cultivated under different conditions and compared to the colony diameters under optimal conditions. Those ratios were compared according the following arbitrary scale: lower than $0.5=$ very sensitive; between 0.5 
and $0.99=$ sensitive; between 1.0 and $1.5=$ moderately tolerant; greater than $1.5=$ tolerant.

- Salt tolerance. Tolerance to sodium chloride $(\mathrm{NaCl})$ was determined by measuring colony growth of the rhizobia strains incubated at 28 ${ }^{\circ} \mathrm{C}$ for six days on YEM solid medium supplemented with 25, 50, 75 and $100 \mathrm{mM} \mathrm{NaCl}$. The negative control was YEM without $\mathrm{NaCl}$.

Table 1. Origin of rhizobia strains used for common bean plant nodulation test

\begin{tabular}{|c|c|c|c|c|c|c|c|}
\hline $\mathrm{N}^{\circ}$ & Reference & Origin & Isolation year & $\mathrm{N}^{\circ}$ & Reference & Origin & Isolation year \\
\hline 1 & CIAT899 & $\begin{array}{l}\text { International Center for } \\
\text { Tropical Agriculture }\end{array}$ & 1899 & 29 & КНТ3.96 & Nabeul-Tunisia & 1996 \\
\hline 2 & Alia1 & Bizerte-Tunisia & 1996 & 30 & Ar3 & Ariana-Tunisia & 2008 \\
\hline 3 & Alia2.96 & Bizerte-Tunisia & 1996 & 31 & Ar1 & Ariana-Tunisia & 2008 \\
\hline 4 & Tinja & Bizerte-Tunisia & 1993 & 32 & Ar6 & Ariana-Tunisia & 2008 \\
\hline 5 & $\mathrm{Ar02}$ & Ariana-Tunisia & 2002 & 33 & Ar4 & Ariana-Tunisia & 2008 \\
\hline 6 & Ar05 & Ariana-Tunisia & 2005 & 34 & Ar2 & Ariana-Tunisia & 2008 \\
\hline 7 & P.Ar.09 & Ariana-Tunisia & 2009 & 35 & $\mathrm{~S} 1$ & Ariana-Tunisia & 1994 \\
\hline 8 & P.Bj & Beja-Tunisia & 2009 & 36 & $\mathrm{~J} 1.96$ & Bizerte-Tunisia & 1996 \\
\hline 9 & P.OM.09 & Oued Meliz-Tunisia & 2009 & 37 & $\mathrm{~J} 2.96$ & Bizerte-Tunisia & 1996 \\
\hline 10 & P.Ps. 09 & Phosphate Gafsa-Tunisia & 2009 & 38 & J3.96 & Bizerte-Tunisia & 1996 \\
\hline 11 & $\mathrm{CB}$ & Cap bon-Tunisia & 1993 & 39 & $\mathrm{~J} 1.92$ & Bizerte-Tunisia & 1996 \\
\hline 12 & P.Tb.09 & Teboursek-Tunisia & 2009 & 40 & $\mathrm{~J} 3.92$ & Bizerte-Tunisia & 1992 \\
\hline 13 & SOM & Maroc & 1998 & 41 & $\mathrm{~J} 4.92$ & Bizerte-Tunisia & 1992 \\
\hline 14 & D4.007 & INRA Montpellier & 2007 & 42 & S3 & Ariana-Tunisia & 1994 \\
\hline 15 & D4.002 & INRA Montpellier & 2002 & 43 & S7 & Ariana-Tunisia & 1994 \\
\hline 16 & KHS1 & INRA Montpellier & - & 44 & S9 & Ariana-Tunisia & 1994 \\
\hline 17 & KHS2 & INRA Montpellier & - & 45 & S11 & Ariana-Tunisia & 1994 \\
\hline 18 & GB.92 & INRA Montpellier & 1992 & 46 & Raf .Raf & Bizerte-Tunisia & 1992 \\
\hline 19 & GB. 258 & INRA Montpellier & 1992 & 47 & Ras.JB & Bizerte-Tunisia & 1992 \\
\hline 20 & KH28 & INRA Montpellier & - & 48 & Soudan 1.2 & Nabeul-Tunisia & 2007 \\
\hline 21 & Fr1.97 & Fernana-Tunisia & 1997 & 49 & Soudan 2.2 & Nabeul-Tunisia & 2007 \\
\hline 22 & $\mathrm{OM}$ & Oued Méliz-Tunisia & 2001 & 50 & D2.2 & Bizerte-Tunisia & 2002 \\
\hline 23 & Mat.9 & Mateur-Tunisia & 1994 & 51 & D3.2 & Bizerte-Tunisia & 2002 \\
\hline 24 & Zaar & Mateur-Tunisia & 1996 & 52 & Artn1 & Ariana-Tunisia & 2002 \\
\hline 25 & ZG.96 & Zaghouan-Tunisia & 1996 & 53 & Ic. 208 & Ariana-Tunisia & 2002 \\
\hline 26 & B155 & CIRAD & - & 54 & 12.a3 & Ariana-Tunisia & 2002 \\
\hline 27 & $\mathrm{~S} 10$ & Ariana-Tunisia & 1994 & 55 & YH15 & Ariana-Tunisia & 2002 \\
\hline 28 & KHT1.96 & Nabeul-Tunisia & 1996 & & & & \\
\hline
\end{tabular}

- Ability of rhizobia to tolerate pH variation. YEM agar medium with $\mathrm{pH}$ adjusted to 4, 5, 6, 7, 8 or 9 using $\mathrm{NaOH}$ or $\mathrm{HCl}$ was used to test the ability of the 55 strains to grow in acidic or alkaline media.

- Tolerance of rhizobia to temperature variation. YEM agar plates were inoculated and incubated at 10 to $40{ }^{\circ} \mathrm{C}$ to study colony growth, determined by measuring their change in diameter.

- Lime-scale concentration. The ability of the 55 rhizobia strains to tolerate limestone was evaluated on YEM agar supplemented with Congo red, containing $0.05 \mathrm{mM}, 0.10 \mathrm{mM}, 0.15 \mathrm{mM}$, and $0.20 \mathrm{mM} \mathrm{CaCO}$. Samples were incubated at 28 ${ }^{\circ} \mathrm{C}$, and colony diameters were measured after six days. Each treatment was repeated four times.
- Biochemical substrate assimilation. API galleries (API 20E; BioMerieux) were used to test Rhizobium strains' assimilation and fermentation of carbohydrates and enzymatic activity, according to Kersters and Deley (1984). Strain inoculants were grown on YEM agar plate cultures, and then the bacteria were washed and re-suspended in $100 \mathrm{~mL}$ of a Bergersen solution (Vincent, 1970). Strain galleries were incubated at $28{ }^{\circ} \mathrm{C}$, and results were recorded after $2-3$ days.

Harvest and data analysis. Plants in pots were inoculated, under greenhouse conditions, with each Rhizobium bacteria strain. For each treatment, four plants were harvested in their early flowering stage. Nodules were removed from the roots, and plants were separated into roots and shoots before drying at $70{ }^{\circ} \mathrm{C}$ in an oven for 72 
hours. Dry weights were measured, and shoot samples were individually ground to determine the $\mathrm{N}$ content based on the Kjeldahl method. The complete root system with nodules of the four plants inoculated with the same strain was pooled to conduct field trials. The shoots and roots of each plant were gently rinsed and placed in paper bags. Symbiotic parameters were measured, including the nodule dry weight (NDW), nodule number, shoot and root dry weight (SDW, RDW), and nitrogen content per plant during the flowering stage.

Statistical analysis. The SPSS statistical program (v. 20) was used for ANOVA, and Duncan's multiple range test for mean comparisons.

\section{RESULTS}

\section{Nodulation test}

- Nodule number and biomass. A high level of variability was detected among the nodule number and dry weight of the 55 tested rhizobia strains (Table 2). Strain Ar02 produced the most nodules (134) and the highest dry weight $(0.0375 \mathrm{~g}$ per plant). Allia02.96 was the second most productive, with 89 nodules and $0.02 \mathrm{~g}$ per plant of dry weight. Although the nodules of most nodulating strains were approximately the same size, examining the proportionality between the number and the weight of the nodules revealed that strain Allia02.96 had smaller nodules than other strains.

- Common bean shoot and root biomass production. The results of biomass production assays are shown in Table 3. Rhizobia strain inoculation caused the shoot dry weight to increase. Specifically, the strains P.Ps, Alia2.96, Ar02, and Ar05 produced the greatest shoot dry biomass weight, from 0.505 to $0.437 \mathrm{~g}$ per plant.

The root dry weight was also affected by rhizobia inoculation. Plants inoculated with strains S3, S11, Soudan2.2, B155, D2.2, Tinja, S9, Ic.208, and Alia1 exhibited enhanced root growth. Root biomass varied from 0.267 to $0.17 \mathrm{~g}$ per plant. The remaining strains were not significantly different from the control in root biomass production.

Some rhizobia strains enhanced both root and shoot weight. This balance of growth between the shoot and root obtained using many of these rhizobia indicates that specific strains are promising bacteria for enhancing growth in common bean plants.

- Nitrogen content. Nitrogen content in common bean shoots inoculated with rhizobia strains varied between $2.85 \%$ and $1.19 \%$ (Table 4). We distinguished up to seven rhizobia strain classes of shoot nitrogen content in the common bean. The most important class of rhizobia strains with regard to nitrogen content included J3.96 (2.85\% N), J3.92 (2.85\%), and KHT1.96 (2.83\%).

Physiological testing of Rhizobium strains. Rhizobial bacteria showed significant growth variability in culture salinity of 25 to $100 \mathrm{mM}$ $\mathrm{NaCl}$, and exhibited diverse behaviour under $\mathrm{pH}$ variation, with most of the strains tested tolerating basic media ( $\mathrm{pH} 8$ and 9). There were also highly significant growth differences between strains by incubation temperature; only KHS1 and KHT1.96 strains tolerated low temperatures $\left(10{ }^{\circ} \mathrm{C}\right)$, but most grew at higher temperatures, with two strains, P.OM.09 and Ras.JB, showing thermophile behaviour. At $10{ }^{\circ} \mathrm{C}$, growth of Mat.9 and B155 strains was totally inhibited. On the other hand, most strains (60\%) were sensitive in the presence of $\mathrm{CaCO}_{3}$, although D2.2, D3.2, 12.a3, Ar4, KHT3.96, S7, ZG.96, Zaar, Mat.9, KHS2 and GB.258 exhibited good growth at the whole range of calcium concentrations $(0.05 \mathrm{M}$ to $0.20 \mathrm{mM}$ )

Biochemical characterization of rhizobia. The outcomes of different biochemical tests are shown in Figure 1, which illustrates three distinct groups. The first group was formed by 28 rhizobia strains that can be classified into two subgroups. The first subgroup includes a large number of bacteria unable to metabolize IND substrates. The strains of the second subgroup were unable to metabolize IND, H2S, VP, or urea. The strains of the second group were not able to assimilate $\mathrm{H} 2 \mathrm{~S}$, INO, RHA, ARA, IND, SOR, or LCD. The final strain group could not assimilate RHA, INO, SOR, or ARo.

\section{DISCUSSION}

The outcome of the nodule biomass analyses is consistent with the study of Abdi et al. (2014). Furthermore, Voisin et al. (2003) showed that an increase in nodule dry weight was associated with enhanced symbiotic efficiency during nodule growth. In addition, Graham et al. (2004) reported 
that nodule dry weight is a good indicator of symbiotic efficiency and thus an important tool in strain evaluation. However, Koskey et al. (2018) discussed other nitrogen-fixing bacteria, recently identified as beta and gamma Proteobacteria, that form symbiotic relationships with legumes. All Rhizobium strains showed similar ratios of the number of nodules to the weight of the nodules, except strain Allia02.96, which presented smaller nodules than other strains. Most studied strains had almost the same size nodules, and some strains were non-nodulating. Biomass assays revealed that rhizobia strain inoculation caused shoot dry weight to increase.

Nitrogen content in common bean shoots and shoot and root dry weight production was also affected by rhizobia inoculation. Some strains enhanced both shoot and root weight. Some rhizobia strains have been reported to enhance phytohormone production and mineral uptake and reduce the toxic effects of metals, thereby indirectly promoting plant growth and development (Karthik et al., 2017) in polluted agricultural soils.

Table 2. Nodulation assessment (number and biomass) on common bean inoculated root with different rhizobia strains

\begin{tabular}{|c|c|c|c|c|c|}
\hline $\begin{array}{l}\text { Rhizobia } \\
\text { strains }\end{array}$ & $\begin{array}{l}\text { Nodule } \\
\text { number }\end{array}$ & $\begin{array}{c}\text { Nodule dry } \\
\text { weight }\left(\mathrm{g} \cdot \mathrm{pl}^{-1}\right)\end{array}$ & $\begin{array}{c}\text { Rhizobia } \\
\text { strains }\end{array}$ & $\frac{\text { Nodule }}{\text { Number }}$ & $\begin{array}{c}\text { Nodule dry } \\
\text { weight }\left(\mathrm{g} \cdot \mathrm{pl}^{-1}\right)\end{array}$ \\
\hline Ar02 & $134 \mathrm{a}$ & $0.0375 \mathrm{a}$ & Artn1 & $0 \mathrm{j}$ & $0 \mathrm{i}$ \\
\hline Alia2.96 & $89 \mathrm{~b}$ & $0.020 \mathrm{c}-\mathrm{e}$ & Ar3 & $0 \mathrm{j}$ & $0 \mathrm{i}$ \\
\hline $\mathrm{J} 3.92$ & $66.75 \mathrm{c}$ & $0.022 \mathrm{~cd}$ & Ar1 & $0 \mathrm{j}$ & $0 \mathrm{i}$ \\
\hline P.Ar.09 & $66 \mathrm{~cd}$ & $0.025 b c$ & Ar6 & $0 \mathrm{j}$ & $0 \mathrm{i}$ \\
\hline P.Ps & $62 \mathrm{~cd}$ & $0.030 \mathrm{ab}$ & Ar4 & $0 \mathrm{j}$ & $0 \mathrm{i}$ \\
\hline CIAT899 & $54.75 \mathrm{c}-\mathrm{e}^{*}$ & $0.010 \mathrm{f}-\mathrm{h}$ & Ar2 & $0 \mathrm{j}$ & $0 \mathrm{i}$ \\
\hline P.Bj & $51.75 \mathrm{c}-\mathrm{f}$ & $0.020 \mathrm{c}-\mathrm{e}$ & B155 & $0 \mathrm{j}$ & $0 \mathrm{i}$ \\
\hline Tinja & $50.75 \mathrm{c}-\mathrm{f}$ & $0.017 \mathrm{~d}-\mathrm{f}$ & $\mathrm{CB}$ & $0 \mathrm{j}$ & $0 \mathrm{i}$ \\
\hline P.OM.09 & $51 \mathrm{c}-\mathrm{f}$ & $0.020 \mathrm{c}-\mathrm{e}$ & D4.007 & $0 \mathrm{j}$ & $0 \mathrm{i}$ \\
\hline Ar05 & $50 \mathrm{c}-\mathrm{f}$ & $0.017 \mathrm{~d}-\mathrm{f}$ & D4.002 & $0 \mathrm{j}$ & $0 \mathrm{i}$ \\
\hline GB.92 & $47.75 \mathrm{c}-\mathrm{g}$ & $0.020 \mathrm{c}-\mathrm{e}$ & D2.2 & $0 \mathrm{j}$ & $0 \mathrm{i}$ \\
\hline Ras. JB & $44.75 \mathrm{~d}-\mathrm{g}$ & $0.015 \mathrm{~d}-\mathrm{g}$ & D3.2 & $0 \mathrm{j}$ & $0 \mathrm{i}$ \\
\hline GB. 258 & $43.75 \mathrm{~d}-\mathrm{g}$ & $0.017 \mathrm{~d}-\mathrm{f}$ & Fr1.97 & $0 \mathrm{j}$ & $0 \mathrm{i}$ \\
\hline КHT1.96 & $38 \mathrm{e}-\mathrm{h}$ & $0.010 \mathrm{f}-\mathrm{h}$ & YH15 & $0 \mathrm{j}$ & $0 \mathrm{i}$ \\
\hline $\mathrm{J} 1.92$ & 37 e-i & $0.012 \mathrm{e}-\mathrm{h}$ & Ic. 208 & $0 \mathrm{j}$ & $0 \mathrm{i}$ \\
\hline $\mathrm{J} 2.96$ & $32.5 \mathrm{f}-\mathrm{i}$ & $0.012 \mathrm{e}-\mathrm{h}$ & $12 \mathrm{a} 3$ & $0 \mathrm{j}$ & $0 \mathrm{i}$ \\
\hline KHS1 & $28.25 \mathrm{~g}-\mathrm{i}$ & $0.012 \mathrm{e}-\mathrm{h}$ & J1.96 & $0 \mathrm{j}$ & $0 \mathrm{i}$ \\
\hline $\mathrm{OM}$ & $17 \mathrm{~h}-\mathrm{j}$ & $0.010 \mathrm{fgh}$ & J3.96 & $0 \mathrm{j}$ & $0 \mathrm{i}$ \\
\hline P.Tb & $15 \mathrm{ij}$ & $0.005 \mathrm{hi}$ & $\mathrm{J} 4.92$ & $0 \mathrm{j}$ & $0 \mathrm{i}$ \\
\hline KHS2 & $5.25 \mathrm{j}$ & $0.007 \mathrm{~g}-\mathrm{i}$ & КНТ3.96 & $0 \mathrm{j}$ & $0 \mathrm{i}$ \\
\hline KH28 & $4.5 \mathrm{j}$ & $0.000 \mathrm{i}$ & Mat.94 & $0 \mathrm{j}$ & $0 \mathrm{i}$ \\
\hline S7 & $3 \mathrm{j}$ & $0.002 \mathrm{c}-\mathrm{e}$ & Raf. Raf & $0 \mathrm{j}$ & $0 \mathrm{i}$ \\
\hline Zaar & $2.75 \mathrm{j}$ & $0.002 \mathrm{i}$ & $\mathrm{S} 1$ & $0 \mathrm{j}$ & $0 \mathrm{i}$ \\
\hline Soudan12 & $2 \mathrm{j}$ & $0.000 \mathrm{i}$ & S3 & $0 \mathrm{j}$ & $0 \mathrm{i}$ \\
\hline SOM & $1.75 \mathrm{j}$ & $0.000 \mathrm{i}$ & S9 & $0 \mathrm{j}$ & $0 \mathrm{i}$ \\
\hline S11 & $1 \mathrm{j}$ & $0.001 \mathrm{i}$ & S10 & $0 \mathrm{j}$ & $0 \mathrm{i}$ \\
\hline ZG.96 & $0.25 \mathrm{j}$ & $0.000 \mathrm{i}$ & Soudan 22 & $0 \mathrm{j}$ & $0 \mathrm{i}$ \\
\hline Alia1 & $0 \mathrm{j}$ & $0.000 \mathrm{i}$ & Control & $0 \mathrm{j}$ & $0 \mathrm{i}$ \\
\hline
\end{tabular}

Data are the means of four replicates harvested at flowering stage. Means with different letters are significantly different according to Duncan's multiple range test $(P \leq 0.05)$. *More than two letters are represented by the first and last letter 
Table 3. Shoot and root dry weight of common been inoculated with different rhizobia strains

\begin{tabular}{|c|c|c|c|c|c|}
\hline $\begin{array}{l}\text { Rhizobia } \\
\text { strains }\end{array}$ & $\begin{array}{l}\text { Shoot dry weight } \\
\left(\mathrm{g} \cdot \mathrm{pl}^{-1}\right)\end{array}$ & $\begin{array}{l}\text { Root dry weight } \\
\left(\mathrm{g} \cdot \mathrm{pl}^{-1}\right)\end{array}$ & $\begin{array}{l}\text { Rhizobia } \\
\text { Strains }\end{array}$ & $\begin{array}{c}\text { Shoot dry weight } \\
\left(\mathrm{g} \cdot \mathrm{pl}^{-1}\right)\end{array}$ & $\begin{array}{c}\text { Root dry weight } \\
\left(\mathrm{g} \cdot \mathrm{pl}^{-1}\right)\end{array}$ \\
\hline P.Ps & $0.505 \mathrm{a}$ & $0.145 \mathrm{a}-\mathrm{d}$ & Ar3 & $0.355 \mathrm{a}-\mathrm{d}$ & $0.162 \mathrm{~cd}$ \\
\hline Alia2.96 & $0.465 a b$ & $0.13 \mathrm{~b}-\mathrm{d}$ & Artn1 & $0.352 \mathrm{a}-\mathrm{d}$ & $0.13 \mathrm{a}-\mathrm{d}$ \\
\hline Ar02 & $0.445 \mathrm{a}-\mathrm{c}$ & $0.097 \mathrm{~cd}$ & Ras JB & $0.352 \mathrm{a}-\mathrm{d}$ & $0.14 \mathrm{~b}-\mathrm{d}$ \\
\hline Ar05 & $0.437 \mathrm{a}-\mathrm{c}$ & $0.0197 \mathrm{a}-\mathrm{c}$ & Ar6 & $0.352 \mathrm{a}-\mathrm{d}$ & $0.117 \mathrm{~cd}$ \\
\hline GB.92 & $0.425 \mathrm{a}-\mathrm{d}$ & $0.12 \mathrm{~cd}$ & Ar4 & $0.351 \mathrm{a}-\mathrm{d}$ & $0.099 \mathrm{~cd}$ \\
\hline Tinja & $0.42 \mathrm{a}-\mathrm{d}$ & $0.18 \mathrm{a}-\mathrm{d}$ & Ar2 & $0.35 \mathrm{a}-\mathrm{d}$ & $0.095 \mathrm{~cd}$ \\
\hline P.Bj & $0.407 \mathrm{a}-\mathrm{d}$ & $0.115 \mathrm{~b}-\mathrm{d}$ & Ic. 208 & $0.350 \mathrm{a}-\mathrm{d}$ & $0.17 \mathrm{a}-\mathrm{d}$ \\
\hline CIAT899 & $0.405 \mathrm{a}-\mathrm{d}$ & $0.112 b-d$ & $\mathrm{~J} 3.96$ & $0.346 \mathrm{~d}$ & $0.115 \mathrm{~b}-\mathrm{d}$ \\
\hline P.Ar.09 & $0.4 \mathrm{a}-\mathrm{d}$ & $0.13 \mathrm{~b}-\mathrm{d}$ & OM & $0.345 \mathrm{~b}-\mathrm{d}$ & $0.0137 \mathrm{~b}-\mathrm{d}$ \\
\hline $\mathrm{J} 1.92$ & $0.395 \mathrm{~d}$ & $0.117 \mathrm{~b}-\mathrm{d}$ & $\mathrm{J} 2.96$ & $0.345 \mathrm{~b}-\mathrm{d}$ & $0.107 \mathrm{~cd}$ \\
\hline YH15 & $0.392 \mathrm{~b}-\mathrm{d}$ & $0.14 \mathrm{~cd}$ & P.OM.09 & $0.342 \mathrm{~b}-\mathrm{d}$ & $0.14 \mathrm{~b}-\mathrm{d}$ \\
\hline P.Tb & $0.390 \mathrm{a}-\mathrm{d}$ & $0.155 \mathrm{a}-\mathrm{d}$ & KHS2 & $0.32 \mathrm{~b}-\mathrm{d}$ & $0.137 \mathrm{~b}-\mathrm{d}$ \\
\hline $\mathrm{J} 4.92$ & $0.387 \mathrm{~d}$ & $0.102 \mathrm{~cd}$ & КНТ3.96 & $0.312 \mathrm{a}-\mathrm{d}$ & $0.12 b-d$ \\
\hline Alia1 & $0.385 \mathrm{~d}$ & $0.17 \mathrm{c}$ & D2.2 & $0.312 \mathrm{a}-\mathrm{d}$ & $0.185 \mathrm{a}-\mathrm{d}$ \\
\hline $\mathrm{J} 3.92$ & $0.382 \mathrm{a}-\mathrm{d}$ & $0.112 \mathrm{~b}-\mathrm{d}$ & Soudan1.2 & $0.31 \mathrm{~b}-\mathrm{d}$ & $0.105 \mathrm{~cd}$ \\
\hline KH28 & $0.375 \mathrm{a}-\mathrm{d}$ & $0.102 \mathrm{~cd}$ & D4.007 & $0.307 \mathrm{~b}-\mathrm{d}$ & $0.145 \mathrm{a}-\mathrm{d}$ \\
\hline $12 \mathrm{a} 3$ & $0.372 \mathrm{~b}-\mathrm{d}$ & $0.125 \mathrm{a}-\mathrm{d}$ & D3.2 & $0.307 \mathrm{~b}-\mathrm{d}$ & $0.157 \mathrm{a}-\mathrm{d}$ \\
\hline Raf Raf & $0.37 \mathrm{~d}$ & $0.122 \mathrm{~d}$ & Ar1 & $0.305 \mathrm{a}-\mathrm{d}$ & $0.145 \mathrm{~cd}$ \\
\hline S1 & $0.366 \mathrm{a}-\mathrm{d}$ & $0.120 \mathrm{~b}-\mathrm{d}$ & Fr1.97 & $0.297 \mathrm{~d}$ & $0.095 \mathrm{~cd}$ \\
\hline S3 & $0.365 \mathrm{a}-\mathrm{d}$ & $0.267 \mathrm{~cd}$ & S9 & $0.297 \mathrm{~d}$ & $0.177 \mathrm{~cd}$ \\
\hline B155 & $0.365 \mathrm{~d}$ & $0.19 \mathrm{~cd}$ & ZG.96 & $0.295 \mathrm{~cd}$ & $0.122 \mathrm{~b}-\mathrm{d}$ \\
\hline SOM & $0.362 \mathrm{a}-\mathrm{d}$ & $0.14 b-d$ & Zaar & $0.287 \mathrm{~cd}$ & $0.09 \mathrm{~cd}$ \\
\hline GB.258 & $0.362 \mathrm{a}-\mathrm{d}$ & $0.07 \mathrm{~d}$ & $\mathrm{~J} 1.96$ & $0.277 \mathrm{~d}$ & $0.107 \mathrm{~cd}$ \\
\hline S11 & $0.362 \mathrm{a}-\mathrm{d}$ & $0.227 \mathrm{~b}-\mathrm{d}$ & Control & $0.277 \mathrm{~d}$ & $0.1 \mathrm{~cd}$ \\
\hline KHT1.96 & $0.357 \mathrm{a}-\mathrm{d}$ & $0.142 \mathrm{a}-\mathrm{d}$ & $\mathrm{S} 10$ & $0.275 \mathrm{~d}$ & $0.13 \mathrm{~cd}$ \\
\hline S7 & $0.357 \mathrm{a}-\mathrm{d}$ & $0.137 \mathrm{~b}-\mathrm{d}$ & KHS1 & $0.272 \mathrm{~d}$ & $0.152 \mathrm{a}-\mathrm{d}$ \\
\hline Soudan2.2 & $0.357 \mathrm{a}-\mathrm{d}$ & $0.2 \mathrm{~cd}$ & CB & $0.267 \mathrm{~d}$ & $0.112 \mathrm{~cd}$ \\
\hline D4.002 & $0.355 \mathrm{~d}$ & $0.16 \mathrm{~cd}$ & Mat.94 & $0.22 \mathrm{~d}$ & $0.117 \mathrm{~cd}$ \\
\hline
\end{tabular}

Data are the means of four replicates harvested at flowering stage. Means with different letters are significantly different according to Duncan's multiple range test $(P \leq 0.05)$

Table 4. Nitrogen content of common bean plants inoculated with various Rhizobium strains

\begin{tabular}{ll}
\hline \multicolumn{1}{c}{ Rhizobia strains } & \multicolumn{1}{c}{ Nitrogen content $(\%)$} \\
\hline J3.96; J3.92; KHT1.96 & $2.85 \mathrm{a} ; 2.85 \mathrm{a} ; 2.83 \mathrm{a}$ \\
GB.258 & $2.73 \mathrm{ab}$ \\
S10; J2.96; Tinja & $2.48 \mathrm{~b} ; 2.47 \mathrm{~b} ; 2.44 \mathrm{~b}$ \\
Ras.JB ; Ar05 & $2.34 \mathrm{bc} ; 2.33 \mathrm{bc}$ \\
J1.92; OM ; Alia2.96; KHS2; GB.92; S1 & $2.14 \mathrm{c} ; 2.09 \mathrm{c} ; 2.08 \mathrm{c} ; 2.02 \mathrm{c} ; 2.01 \mathrm{c} ; 2.01 \mathrm{c}$ \\
P.Bj; CIAT899; D4.002; Ar6; YH15; Ar4; & $1.96 \mathrm{~cd} ; 1.94 \mathrm{~cd} ; 1.94 \mathrm{~cd} ; 1.94 \mathrm{~cd} ; 1.94 \mathrm{~cd} ; 1.92 \mathrm{~cd} ; 1.92 \mathrm{~cd} ; 1.91 \mathrm{~cd}$ \\
P.Ps; Ar02; Ar1; Soudan1.2 & $; 1.89 \mathrm{~cd} ; 1.89 \mathrm{~cd}$ \\
Control; SOM; D2.2; KHS1 & $1.85 \mathrm{~d} ; 1.85 \mathrm{~d} ; 1.82 \mathrm{~d} ; 1.80 \mathrm{~d}$ \\
S7; Fr1.97; P.Tb ; S3; J1.96; P.Ar.09; & $1.73 \mathrm{de} ; 1.71 \mathrm{de} ; 1.67 \mathrm{de} ; 1.67 \mathrm{de} ; 1.66 \mathrm{de} ; 1.66 \mathrm{de} ; 1.66 \mathrm{de} ; 1.66 \mathrm{de}$ \\
KH28; S11 & \\
CB ; Artn1; Mat.94; KHT3.96 & $1.63 \mathrm{e} ; 1.63 \mathrm{e} ; 1.61 \mathrm{e} ; 1.6 \mathrm{e}$ \\
P.OM.09; S9; Ar3; Ar2; Raf .Raf; D4.007; & $1.56 \mathrm{ef} ; 1.56 \mathrm{ef} ; 1.55 \mathrm{ef} ; 1.53 \mathrm{ef} ; 1.49 \mathrm{ef} ; 1.49 \mathrm{ef} ; 1.47 \mathrm{ef} ; 1.46 \mathrm{ef} ;$ \\
D3.2; B155, Ic.208; & $1.45 \mathrm{ef}$ \\
12.a3; Zaar; ZG.96; J4.92 & $1.34 \mathrm{f} ; 1.32 \mathrm{f} ; 1.32 \mathrm{f} ; 1.27 \mathrm{f}$ \\
Soudan2.2 & $1.25 \mathrm{fg}$ \\
Alia1 & $1.19 \mathrm{~g}$ \\
\hline Data are the means of four replicates harvested at flowering stage. Means with different letters are significantly different \\
according to Duncan's multiple range test $(P \leq 0.05)$
\end{tabular}




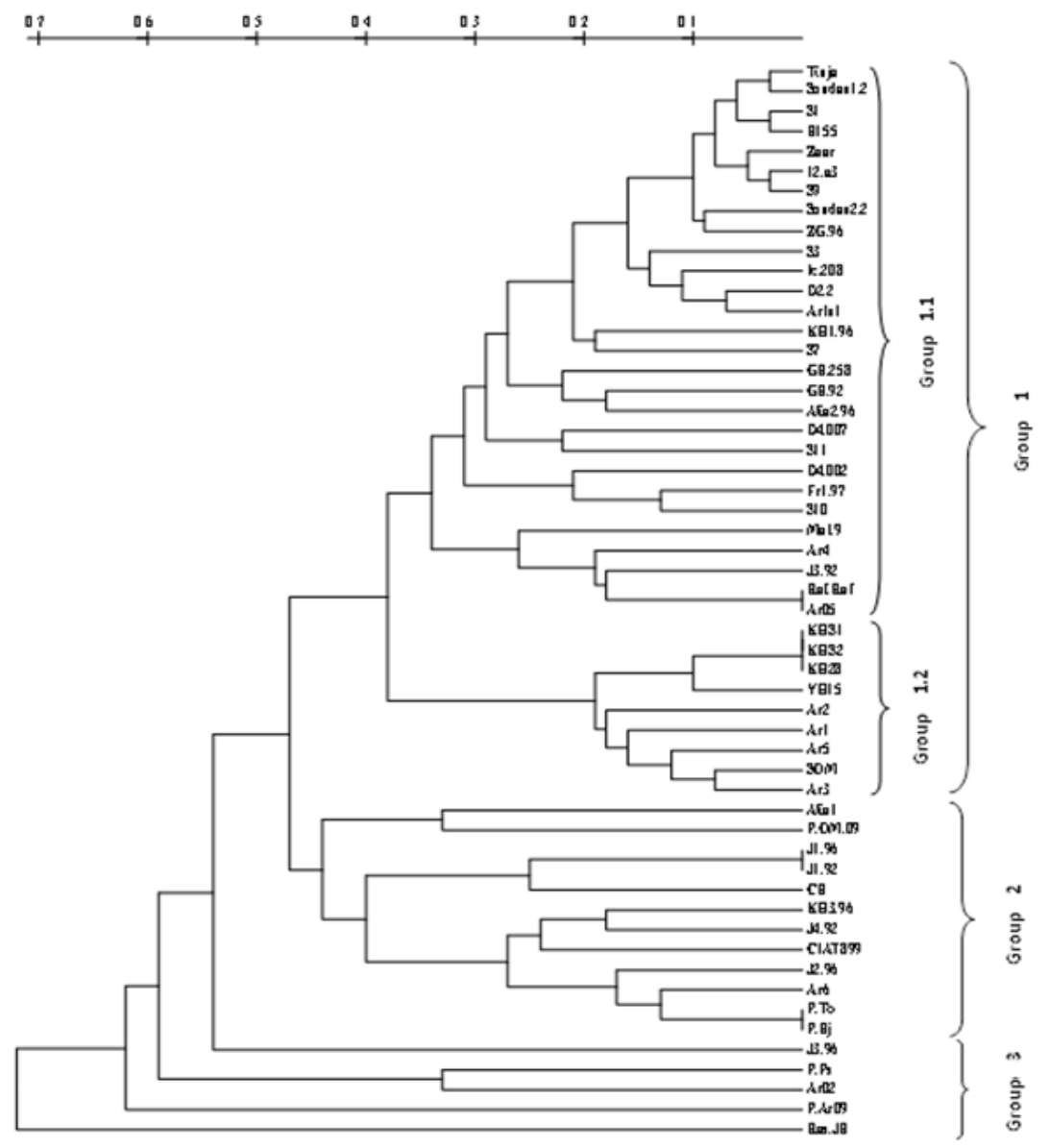

Figure 1. Rhizobia strains distribution according to their capability to assimilate various biochemical substrates

The Rhizobium strains demonstrated diverse capabilities of metabolizing specific carbohydrate and organic acid substrates and three large groups were formed as shown in Figure 1. In that sense, Diange and Lee (2013) found that strains of $R$. sullae, $R$. etli, $R$. gallium, and $R$. indigolferae did not react with various carbon substrates. They also demonstrate that strains of $R$. yanglingense and $R$. monogolense have a lower use of such substrates. However, the latter strain assimilated Dmelibiose, L-arabinose, and L-rhamnose and had negative fermentation reactions with inositol, Dsucrose, D-mannitol, and amygdalin. Van Rossum et al. (1994) believed that rapidly growing strains preferred disaccharides, hexoses, organic acids, and pentoses. The same outcomes have been observed by Lindström and Lehtomaki (1988) regarding Rhizobium galeagae strains. Jordan (1984) believed that slowly growing strains rarely used monosaccharides, but variably used disaccharides. The outcome confirmed the observations of $\mathrm{Xu}$ (1995) for Bradyrhizobium japonicum and Bradyrhizobium liaoningense. The development of rhizobia in the soil is highly dependent on the flavonoid compounds, which may be used as a primary carbon source by slow-growing and fast-growing strains. Bradyrhizobiacea demonstrates greater use of these compounds (Parke and Ornston, 1984). Urea hydrolyzation and nitrate reduction are critical elements in choosing a specific strain. Sherwood et al. (1984) believed that a higher amount of soil nitrate would hinder the symbiotic efficiency of rhizobia within the root surface.

The degree of salt tolerance in the culture medium varied between strains. These results confirm those of Aouni et al. (1986), who showed that bacteria collected from nodules of plants of the genera Phaseolus, Vicia, Pisum, Trifolium, Cicer, and Glycine could tolerate up to $3 \mathrm{~g} \cdot \mathrm{L}^{-1}$ of 
$\mathrm{NaCl}(51 \mathrm{mM})$ and are unable to grow at $11 \mathrm{~g} \cdot \mathrm{L}^{-1}$ $(186 \mathrm{mM})$. This result is confirmed by Jebara et al. (2001), who showed that the bean variety Batt477 inoculated and hydroponically grown with indigenous strains from Tunisia were particularly tolerant to salinity. Similar results were observed by El Sheikh and Wood (1989). El Boutari (2009) reported that $R$. sullae strains tolerated salt between 170 and $850 \mathrm{mM} \mathrm{NaCl}$. However, Squartini et al. (2002) found a lower tolerance range, ranging from 290 to $548 \mathrm{mM} \mathrm{NaCl}$. Much higher salinity tolerance levels (1190-1700 mM $\mathrm{NaCl})$ have been reported for rhizobial strains nodulating lupine (Raza et al., 2001).

The Rhizobium strains studied exhibited diverse behaviours with respect to $\mathrm{pH}$ variation in the medium. These results are confirmed by Maâtallah et al. (2001), who examined strains nodulating chickpeas that exhibited great variability in their $\mathrm{pH}$ tolerance, and found that 90 to $100 \%$ of the isolates could grow in media with $\mathrm{pH}$ between 6 and 8 ; this trend could be related to the $\mathrm{pH}$ value ranges of soils from which the tested isolates were collected.

Graham (1998) found variability in acid tolerance for strains of $R$. tropici UMR 1999 and PRF 81 and recommended them for P. vulgaris in acidic soils of Brazil. According to Jordan (1984), rhizobia can tolerate $\mathrm{pH}$ values ranging from 4.5 to 9. Notably, our studied strains demonstrated rapid growth rates, generally tolerated alkalinity, and were sensitive to acidity. Zablotowicz and Focht (1981) reported that slow-growing strains that nodulate Vigna unguiculata were more sensitive to alkaline $\mathrm{pH}$ than fast-growing ones. Other studies have shown that fast-growing rhizobia are more sensitive to acidity than the previously mentioned bradyrhizobia (Van Rossum et al., 1994).

There were notorious differences in bacterial colony growth depending on incubation temperature. Most strains were influenced by high temperatures $\left(40{ }^{\circ} \mathrm{C}\right)$, except P.OM.09 and Ras.JB strains that demonstrated thermophile behaviour. Graham (1992) reported that rhizobia are mesophilic bacteria that can grow at temperatures between 10 and $37^{\circ} \mathrm{C}$ and that most strains grow at an optimum temperature of $28{ }^{\circ} \mathrm{C}$. However, some studies have shown strains that tolerate extreme temperatures, such as those which nodulate certain legumes in arctic regions
(Lipsanen and Lindstrôm, 1989) or those isolated in the hot and dry environment of the Sahel savannah in Africa, such as strains of $R$. phaseoli, that could tolerate temperatures of 45 to $47{ }^{\circ} \mathrm{C}$ (Karanja and Wood, 1988). Also, strains of $R$. leguminosarum isolated from lentil plants in the Nile Valley, and rhizobia of leguminous trees can tolerate temperatures of $40{ }^{\circ} \mathrm{C}$ (Moawad and Beck, 1991, De Lajudie et al., 1998). Bradyrhizobia have been reported to be more thermotolerant than rapidly growing strains (Munevar and Wollum, 1981). Tolerance at 48.7 ${ }^{\circ} \mathrm{C}$ has been reported for some strains of Bradyrhizobium japonicum (Munevar and Wollum, 1981). Almost all rhizobial strains in the current study did not tolerate low temperature (10 $\left.{ }^{\circ} \mathrm{C}\right)$, except for KHS1 and KHT1.96. At such a temperature the growth of Mat.9 and B155 strains was completely inhibited, which, on the contrary, tolerated temperatures of $40{ }^{\circ} \mathrm{C}$. Low temperatures have been reported to be among the main factors limiting nitrogen fixation by rhizobia in very humid or cold regions (Zhang and Smith, 1996), and high temperatures have been observed to produce a similar effect (Hungria and Franco, 1993). However, high temperatures inhibited strain multiplication, can reduce the number of cells below the level required for good nodulation, can lead to the loss of the symbiotic plasmid and, consequently, the bacteria's infective ability. Somasegaran and Hoben (1984) showed a gradual decline in the persistence of a population of Rhizobium strains incubated at $37{ }^{\circ} \mathrm{C}$ over eight weeks.

Rhizobia can maintain good performance when used in an environment with climatic conditions similar to their site of origin. However, several authors have reported no correlation between the temperature of the isolation site and the tolerance of strains to heat stress (Mohamed et al., 2000).

Exposure to $\mathrm{CaCO}_{3}$ resulted in significant variability in the growth of these bacteria in culture media supplemented with calcium (Table 5). While some Rhizobium strains exhibited good growth in calcium concentrations up to $2 \mathrm{M}$, strains sensitive to minimal calcium were identified. EL-Hamdaoui et al. (2003) indicated that high calcium levels enhanced rhizobial growth and adsorption to roots and promoted nodulation, leading to an increase in salt tolerance for nodulated legumes. 
Kouki et al.

Diversity of selected rhizobia that nodulate the common bean

Table 5. Effect of abiotic constraints on the growth of the rhizobia strains

\begin{tabular}{|c|c|c|c|c|c|c|c|c|c|c|c|c|c|c|c|c|c|c|}
\hline \multirow{2}{*}{ Rhizobia strain } & \multicolumn{6}{|c|}{$\mathrm{pH}$} & \multicolumn{4}{|c|}{$\mathrm{NaCl}(\mathrm{mM})$} & \multicolumn{4}{|c|}{$\mathrm{CaCO}_{3}(\mathrm{mM})$} & \multicolumn{4}{|c|}{$\mathrm{T}^{\circ} \mathrm{C}$} \\
\hline & 4 & 5 & 6 & 7 & 8 & 9 & 25 & 50 & 75 & 100 & 0.05 & 0.10 & 0.15 & 0.20 & 10 & 20 & 30 & 40 \\
\hline$\overline{\text { CIAT899 }}$ & -- & - & - & ++ & ++ & + & - & - & - & - & -- & - & - & - & -- & - & ++ & - \\
\hline Alia1 & -- & - & - & + & + & + & - & - & - & -- & -- & -- & -- & -- & - & + & ++ & - \\
\hline Alia2.96 & -- & - & - & ++ & ++ & ++ & - & - & - & - & - & - & - & - & -- & + & - & - \\
\hline Tinja & -- & + & - & - & - & + & -- & - & - & - & - & -- & -- & - & -- & - & ++ & - \\
\hline $\mathrm{Ar} 02$ & - & - & + & + & ++ & + & - & - & + & - & - & -- & -- & -- & -- & + & ++ & + \\
\hline Ar05 & -- & - & - & + & ++ & ++ & - & - & - & - & -- & -- & -- & -- & - & + & ++ & + \\
\hline P.Ar.09 & -- & - & - & + & + & - & - & -- & - & - & - & - & - & -- & - & + & - & - \\
\hline P.Bj & -- & - & - & + & + & + & - & -- & - & - & -- & - & - & -- & -- & - & + & + \\
\hline P.OM.09 & -- & + & + & + & + & + & - & - & - & - & - & - & - & - & -- & + & + & + \\
\hline P.Ps. 09 & -- & + & + & + & + & + & - & - & - & - & - & - & - & - & -- & - & ++ & - \\
\hline CB & -- & - & - & + & ++ & ++ & - & - & + & - & - & - & - & - & - & - & - & - \\
\hline P.Tb.09 & - & - & - & + & + & + & - & - & - & - & + & - & - & - & - & ++ & ++ & + \\
\hline SOM & - & - & - & + & + & + & -- & - & + & - & - & + & - & - & - & - & ++ & + \\
\hline D4.007 & + & - & + & ++ & ++ & ++ & + & - & + & ++ & + & - & + & + & - & + & + & + \\
\hline D4.002 & -- & + & - & - & + & ++ & + & + & ++ & + & + & - & - & - & - & + & + & + \\
\hline KHS1 & -- & - & + & + & - & - & - & - & - & -- & -- & - & - & + & + & ++ & ++ & - \\
\hline KHS2 & -- & - & - & ++ & ++ & + & - & - & - & ++ & + & + & + & + & - & + & ++ & - \\
\hline GB.92 & -- & - & - & + & + & + & - & - & - & - & -- & - & -- & - & -- & ++ & - & - \\
\hline GB. 258 & -- & - & -- & + & + & - & -- & -- & - & - & ++ & ++ & ++ & ++ & -- & -- & - & - \\
\hline KH28 & - & -- & - & + & + & - & - & - & - & - & - & - & - & - & - & ++ & ++ & + \\
\hline Fr1.97 & -- & - & - & + & + & - & - & - & + & - & - & - & - & - & - & ++ & ++ & - \\
\hline $\mathrm{OM}$ & -- & - & - & + & ++ & ++ & - & + & + & + & + & + & + & - & -- & + & - & - \\
\hline Mat.9 & -- & - & - & + & + & + & + & + & ++ & ++ & + & + & + & + & -- & + & + & + \\
\hline Zaar & -- & -- & + & + & ++ & + & + & + & + & + & + & + & + & + & -- & - & + & - \\
\hline ZG.96 & -- & - & - & + & + & ++ & + & + & + & + & + & + & + & + & -- & ++ & + & + \\
\hline B155 & -- & - & - & + & + & + & - & - & - & - & - & - & -- & -- & -- & + & - & - \\
\hline S10 & -- & -- & - & + & + & + & -- & - & - & -- & - & - & - & - & - & - & ++ & + \\
\hline KHT1.96 & -- & -- & -- & - & + & - & - & - & - & - & -- & -- & -- & -- & + & + & ++ & + \\
\hline КНT3.96 & -- & + & ++ & + & - & - & + & ++ & ++ & ++ & + & + & + & + & -- & -- & + & - \\
\hline Ar3 & -- & - & - & ++ & ++ & + & - & - & + & + & - & - & - & - & - & ++ & ++ & + \\
\hline Ar1 & -- & + & + & + & ++ & ++ & + & - & + & + & - & + & + & - & - & + & ++ & - \\
\hline Ar6 & -- & -- & - & - & - & + & -- & - & - & -- & -- & -- & -- & -- & -- & + & ++ & - \\
\hline Ar4 & -- & -- & + & ++ & ++ & - & + & ++ & ++ & ++ & ++ & ++ & ++ & + & -- & - & + & - \\
\hline Ar2 & - & -- & -- & - & - & - & - & -- & -- & - & -- & -- & -- & -- & -- & - & - & - \\
\hline $\mathrm{S} 1$ & -- & - & - & ++ & + & - & - & - & - & - & - & - & - & - & - & - & ++ & + \\
\hline J1.96 & -- & - & - & ++ & ++ & ++ & - & - & - & - & -- & -- & -- & -- & - & + & + & - \\
\hline $\mathrm{J} 2.96$ & -- & - & - & ++ & + & + & - & + & + & + & - & - & - & - & -- & - & + & -- \\
\hline J3.96 & -- & - & - & ++ & + & + & - & - & - & + & - & - & - & - & - & + & ++ & - \\
\hline J1.92 & -- & - & + & ++ & ++ & ++ & - & + & ++ & ++ & - & - & - & - & - & - & + & - \\
\hline $\mathrm{J} 3.92$ & -- & - & - & + & + & + & - & -- & - & - & - & -- & -- & - & - & + & + & + \\
\hline $\mathrm{J} 4.92$ & -- & - & - & - & - & - & -- & -- & - & - & -- & -- & -- & -- & - & + & ++ & - \\
\hline S3 & -- & -- & - & - & - & -- & -- & - & - & - & -- & -- & -- & -- & - & - & - & - \\
\hline S7 & -- & -- & - & + & - & - & -- & -- & - & - & + & ++ & + & + & - & + & ++ & - \\
\hline S9 & -- & -- & + & + & + & + & - & - & + & + & - & - & -- & - & -- & -- & + & - \\
\hline S11 & -- & - & - & + & ++ & ++ & - & + & - & -- & - & - & - & - & - & - & - & - \\
\hline Raf .Raf & -- & -- & - & - & ++ & ++ & - & - & - & + & + & + & + & - & - & - & ++ & + \\
\hline Ras.JB & -- & -- & -- & -- & -- & -- & -- & -- & -- & - & -- & -- & -- & -- & -- & + & + & ++ \\
\hline Soudan 1.2 & -- & -- & - & ++ & + & - & - & + & + & ++ & - & - & - & + & -- & - & - & - \\
\hline Soudan 2.2 & -- & - & - & + & + & + & - & + & + & + & + & + & + & - & -- & + & ++ & + \\
\hline D2.2 & -- & -- & + & ++ & + & + & + & + & ++ & ++ & ++ & ++ & + & + & -- & - & - & - \\
\hline D3.2 & -- & -- & - & ++ & + & + & - & - & - & - & ++ & ++ & ++ & ++ & -- & - & - & - \\
\hline Artn1 & -- & -- & - & - & - & - & - & - & - & - & -- & -- & -- & + & -- & + & ++ & + \\
\hline Ic. 208 & -- & -- & - & + & ++ & ++ & + & + & - & - & - & - & - & - & -- & + & ++ & - \\
\hline 12.a3 & -- & - & - & - & - & + & + & + & - & -- & + & + & + & + & -- & -- & + & -- \\
\hline YH15 & -- & -- & - & - & + & ++ & - & ++ & ++ & + & - & - & - & - & - & + & - & - \\
\hline
\end{tabular}

-- Very Sensitive, - Sensitive, + Moderately Tolerant, ++ Tolerant 
Changes in temperatures, metal toxicity, $\mathrm{pH}$ and soil salinity are among the main factors restricting symbiotic nitrogen fixation in legumerhizobia symbiosis, where only those strains capable of tolerating extreme conditions survive (Berrada et al., 2012). The production of extracellular polysaccharides by most isolates in this study could indicate their versatility to withstand physiological stress due to those restricting factors (Karthik et al., 2017).

\section{CONCLUSIONS}

Rhizobium strains showed significant variation in their symbiotic capabilities while responding to various controlled conditions and abiotic constraints, showing variability in nodulating potential (nodule number and weight), shoot and root biomass production. Some of them exhibited tolerance to $\mathrm{pH}$, salt, $\mathrm{CaCO}_{3}$ and temperature, and finally, capability to metabolize specific biochemical substrates. Tunisian strains Ar02 and Allia02.96 were the most nodulating rhizobia and highest dry weight strains. They also demonstrated efficient production of the shoot and root biomass in the common bean. Other Rhizobium strains, including J3.96, J3.92, and KHT1.96, demonstrated substantial nitrogen content.

The studied strains exhibited diverse behaviours with respect to the variation in the $\mathrm{pH}$, with most of the strains tolerating basic media. Also, Rhizobial bacteria showed growth variability in culture salinity of 25 to $100 \mathrm{mM}$ $\mathrm{NaCl}$. Regarding temperatures, almost no strain tolerated low temperatures, but most grew at higher temperatures, with two strains showing thermophile behavior. At the lowest temperature, the growth of some strains was totally inhibited, but they showed notorious growth at very high temperatures. Furthermore, some Rhizobium strains exhibited good growth in a medium containing up to $2 \mathrm{M}$ calcium, but some strains could not tolerate even low calcium concentrations. The rhizobia strains also demonstrated diversity in their capability to metabolize specific biochemical substrates, such as carbohydrates and organic acids.

\section{LITERATURE CITED}

1. Abdi, N., B. L’taief, I. Hemissi, M. Bouraoui,
H. Maazaoui and B. Sifi. 2014. Nitrogen and phosphorus fertilization effect on rhizobiacommon bean symbiosis. Annales de l'INRAT 87: 21-33.

2. Aouni, M. E., R. Mhamdi, M. Mars and R. Ghrir. 1986. Modulation and growth of common bean under $\mathrm{NaCl}$ stress. Soil Biology and Biochemistry 301: 473-475.

3. Bargaz, A., M. Faghire, N. Abdi, M. Farissi, B. Sifi, J. J. Drevon, M. C. Ikbal and C. Ghaulam. 2012. Low soil phosphorus availability increases acid phosphatases activities and affects partitioning in nodules, seeds and rhizosphere of Phaseolus vulgaris. Agriculture 2: 139-153.

4. Berrada, H., I. Nouijoui, M. I. Hassaini, N. El Ghachtali, M. Gtari and F. K. Ben Brahim. 2012. Phenotypic and genotypic characterizations of rhizobia isolated from root nodules of multiple legume species native of Fez Morocco. African Journal of Microbiology Research 6(25): 5314-5324.

5. Cao, Y., E. T. Wang, L. Zhao, W. M. Chen and G. H. Wei. 2014. Diversity and distribution of rhizobia nodulated with Phaseolus vulgaris in two ecoregions of China. Soil Biology and Biochemistry 78: 128-137.

6. Chekani, V., R. Chikowo and B. Vanlauwe. 2018. Response of common bean (Phaseolus vulgaris L.) to nitrogen, phosphorus and rhizobia inoculation across variable soils in Zimbabwe. Agriculture, Ecosystems and Environment 266: 167-173.

7. De Lajudie, P., A. Willems, G. Nick, E. Moreira, F. Moulouba, B. Hoste et al. 1998. Characterization of tropical tree rhizobia and description of Mesorhizobium plurifarium sp. nov. International Journal of Systematic Bacteriology 48: 369-382.

8. Diange, E. A. and S. S. Lee. 2013. Rhizobium halotolerans sp. nov., isolated from Chloroethylene contaminated soil. Current Microbiology 66: 599-605.

9. El Attar, I., K. Taha, B. El Bekkay, M. El Khadir, T. I. Alami and J. Aurag. 2019. Screening of stress tolerant bacterial strains possessing interesting multiplant growth promoting traits isolated from root nodules of Phaseolus vulgaris L. Biocatalysis and 
Agricultural Biotechnology 20: 101-225.

10.El Sheikh, E.A. and M. Wood. 1989. Response of chickpea and soybean rhizobia to salt:influence of carbon source, temperature and pH. Soil Biology. Biochemistry 21: 883887.

11.El Boutari, N. 2009. Etude phénotypique et génotypique d'une collection de Sinorhizobiummeliloti et de Rhizobium sullae. Université Mohammed VAgdal, Faculté des Sciences, Rabat. Retrieved from https://n9.cl/vea6w.

12.El-Hamdaoui, A., R. N. Miguel, R. Rafael, B. Luis and Ildefonso B. 2003. Effects of boron and calcium nutrition on the establishment of the Rhizobium leguminosarum-pea (Pisum sativum) symbiosis and nodule development under salt stress. Plant Cell and Environment 26(7): 1003-1011.

13.Graham, J.H., T. R. Gottwald, J. Cubero and D. S. Achor. 2004. Xanthomonas axonopodis pv. citric: factors affecting successful eradication of citrus canker. Molecular Plant Pathology 5(1): 1-15.

14.Graham, P.H. 1992. Stress tolerance in Rhizobium and Bradyrhizobium, and nodulation under adverse soil conditions. Canadian Journal Microbiology 38: 475-484.

15.Graham, P.H. 1998. Symbiotic nitrogen fixation. In: D. Sylvia et al. (eds.). Principles and Applications of Soil Microbiology. Prentice Hall, UK. pp. 325-347.

16.Hungria, M. and A. A. Franco. 1993. Effect of high temperature on nodulation and nitrogen fixation by Phaseolus vulgaris L. Plant and Soil. 149: 95-102.

17.Hungria, M., M. A. Nogueiro and R. S. Araujo. 2015. Soybean Seed Co-Inoculation with Bradyrhizobium spp. and Azospirillum brasilense: A New Biotechnological Tool to Improve Yield and Sustainability. American Journal of Plant Sciences 6: 811-817.

18.Hungria, M., R. J. Campo and I. C. Mendes. 2003. Benefits of inoculation of the common bean (Phaseolus vulgaris) crop with efficient and competitive Rhizobium tropici strains. Biology and Fertility of Soils 39: 88-93.

19.Jebara, M., J. J. Drevon and M. E. Aouani.
2001. Effects of hydroponic culture system and $\mathrm{NaCl}$ on interactions between common bean lines and native rhizobia from Tunisian soils. Agronomie. 21: 601-605.

20.Jordan, D.C. 1984. Rhizobiaceae. In: Kreig, N. R. (ed.) Bergey's Manual of Systematic Bacteriology 1: 234-256.

21.Karanja, N. K. and M. Wood. 1988. Selecting Rhizobium phaseoli strains for use with beans (Phaseolus vulgaris L.) in Kenya. Tolerance of high temperature and antibiotic resistance. Plant Soil 112: 15-22.

22.Karthik, C., M. Oves, K. Sathya, V. Sri Ramkumar and P. Arulselvi. 2017. Isolation and characterization of multi-potential Rhizobium strain ND2 and its plant growthpromoting activities under Cr (VI) stress. Arch. Agron. Soil Sci. 63: 1058-1069.

23.Kaymakanova, M., N. Stoeva and T. Mincheva. 2008. Salinity and its effect on physiological response of bean (Phaseolus vulgaris L.). Central European Agriculture 9(4): 749-756.

24.Kersters, K. and J. Deley. 1984. Genus III. Agrobacterium, Conn 1942. In: B. Holt et al. (eds.), Bergey's Manual of Systematic Bacteriology. The Williams and Wilkins Co. Baltimore, MD, USA. pp. 224-225.

25.Koskey, G., W. M. Simon, J. Kimiti, O. Ombori, J. M. Maingi and E. Njeru. 2018. Genetic characterization and diversity of Rhizobium isolated from root nodules of midAltitude climbing bean (Phaseolus vulgaris L.) varieties. Frontiers of Microbiology 9: 918.

26.Kumar, P., P. Pandey, R. C. Dubey and D. K. Maheshwari. 2016. Bacteria consortium optimization improves nutrient uptake, nodulation, disease suppression and growth of the common bean (Phaseolus vulgaris) in both pot and field studies 2: 13-23.

27.Lindström, K. and S. Lehtomaèki. 1988. Metabolic properties, maximum growth temperature and phage sensitivity of Rhizobium sp. (Galega) compared with other fast-growing rhizobia. FEMS Microbiology Letters 50: 277-287.

28.Lipsanen, P. and K. Lindström. 1989. Lipopolysaccharide and protein patterns of Rhizobium sp. (Galega). FEMS Microbiology. 
Letters. 58: 323-328.

29.Maâtallah, J., E. B. Berraho, J. Sanjuan and C. Liuch. 2001. Phenotypic characterization of rhizobia isolated from chickpea (Cicer arietinum) growing in Moroccan soils. Agronomie 22: 321-329.

30.Meng, L., A. Zhang, F. Wang, X. Han, D. Wang and S. Li. 2015. Arbuscular mycorrhizal fungi and Rhizobium facilitate nitrogen uptake and transfer in soybean/maize intercropping system. Front. Plant Sci. 6:339.

31.Moawad, H. and Beck D. 1991. Some characteristics of Rhizobium leguminosarium isolates from uninoculated filed-grown lentils. Soil. Biochemistry 23: 917-925.

32.Mohamed, S.H., A. Smouni, M. Neyra, D. Kharchaf and A. Filali-Matouf. 2000. Phenotypic characteristics of root-nodulating bacteria isolated from Acacia spp. grown in Libya. Plant et Soil. 224: 171-183.

33.Munevar, F. and A. G. Wollum. 1981. Effect of high root temperature and rhizobium strain on nodulation, nitrogen fixation, and growth of soybeans. Soil Science Society of America Journal 45: 1113-1120.

34.Musandu, A. A. O. and O. J. Ogendo. 2001. Response of Common Bean to Rhizobium Inoculation and Fertilizers. Journal of Food Technology in Africa 6: 121-125.

35.Mwenda, G. M., G. W. O'Hara, S. E. De Meyer, J. G. Howieson, and J. J. Terpolilli. 2018. Genetic diversity and symbiotic effectiveness of Phaseolus vulgaris nodulating rhizobia in Kenya. Systematic and Applied Microbiology 41: 291-299.

36.Parke, C. and L. N. Ornston. 1984. Nutritional diversity of Rhizobiaceae revealed by auxanography. Journal of General Microbiology 130: 1743-1750.

37.Raza, S., B. H. Jornsgard Abou-Taleb and J. L. Christiansen. 2001. Tolerance of Bradyrhizobium sp. (Lupini) strains to salinity, $\mathrm{pH}, \mathrm{CaCO}_{3}$ and antibiotics. Letters in Applied Microbiology 32: 379-383.

38.Sherwood, J. E., G. L. Truchet and F. B. Dazzo. 1984. Effect of nitrate supply on the in vivo synthesis and distribution of trifoliin $\mathrm{A}$, a Rhizobium trifolii-binding lectin, in Trifolium repens seedlings. Planta 126: 540-547.

39. Somasegaran, P. and H. J. Hoben. 1994. Handbook for Rhizobia: Methods in legumeRhizobia technology. In Springer-Verlag. New York. 450 p.

40.Squartini, A., P. Struffi, H. Doring, S. Pobell, E. Tola, A. Giaconini, E. Vendramin, E.Velazquez, P.F. Mateos, E. Martinez Molina, F.B. Dazzo, S. Casella and M. Nuti. 2002. Rhizobium sullae sp. nov. (formerly 'Rhizobium hedysari'), the root-nodule microsymbiont of Hedysarum coronarium L. International Journal Systematic and Evolutionary Microbiology 52- 1267-1276.

41. Van Rossum, D., A. Muyotcha, B. M. De Hope, H. W. V. Verseveld, A. H. Stouthamer and F. C. Boogerd. 1994. Soil acidity in relation to groundnut-Bradyrhizobium symbiotic performance. Plant Soil. 163: 165-175.

42.Vincent, J.M. 1970. A manual for practical study of root nodule bacteria. IBP Handbook 15. Blackwell Scientific Publications, Oxford.

43. Voisin, A. S., C. Salon, C. Jeudy, and F. R. Warembourg. 2003. Root and Nodule Growth in Pisium sativum in relation to photosynthesis: Analysis using ${ }^{13} \mathrm{C}$-labeling. Annals of Botany 92: 557-563.

44.Xu, S. 1995. Further investigation on the regression method of mapping quantitative trait loci. Heredity 80: 364-373.

45. Yanni, Y., M. Zidan, F. Dazzo, R. Rizk, A. Mehesen, F. Abdelfattah and A. Elsadany. 2016. Enhanced symbiotic performance and productivity of drought-stressed common bean after inoculation with tolerant native rhizobia in extensive fields. Agriculture Ecosystems \& Environment 232: 119-128.

46.Zablotowicz, R. M. and D. D. Focht. 1981. Physiological characteristics of cowpea rhizobia evaluation of symbiotic efficiency in Vigna unguiculata. Applied Environmental Microbiology 41: 679-685.

47.Zhang, F. and Smith D. L. 1996. Inoculation of soybean (Glycine max L. Merr.) with genisteinpreincubated Bradyrhizobium japonicum or genistein directly into soil increases soybean protein and dry matter yield under short season conditions. Plant Soil 179: 233-241. 